\title{
Cytotaxonomic characterization of cultivars and accessions of Lens culinaris Medik. (Fabaceae) from Chile and Canada
}

\section{Caracterización citotaxonómica de cultivares y procedencias de Lens culinaris Medik. (Fabaceae) de Chile y Canadá}

\author{
Ricardo Pino Palma ${ }^{1, *}$, Carlos M. Baeza ${ }^{1}$ \& Tod Stuessy ${ }^{2,3}$ \\ IUniversidad de Concepción, Facultad de Ciencias Naturales y Oceanográficas, Departamento de Botánica, Box 160-C, Concepción, Chile. \\ ${ }^{2}$ The Ohio State University, Department of Evolution, Ecology and Organismal Biology, 1315 Kinnear Road, Columbus, Ohio 43212, USA. \\ ${ }^{3}$ University of Vienna, Department of Botany and Biodiversity Research, Rennweg 14, Vienna, Austria. \\ *E-mail: ricapino@udec.cl
}

\begin{abstract}
The lentil (Lens culinaris Medik.) belongs to the legume family (Fabaceae), and it possesses benefits at nutritional, sustainable, and crop rotation system levels. Its occurrence and consumption in Chile originated from imports from Canada, but molecular tools now group Canadian lentils apart from those of the Mediterranean agro-ecological zones in Chile. Isoenzyme studies have shown a narrow genetic distance between different strains of Chilean germplasm. This present work characterizes Chilean cultivars and regional accessions and compares them with those in Canada using the cytotaxonomic tools of chromosome formula, chromosomal asymmetry index, total chromosome length (TLC), and a detailed architectural examination of each chromosome. We found chromosome stability among all lentils as $4 m+3 \mathrm{sm}$. Results showed a low TLC but higher inter-chromosomal asymmetry in the accessions from Hualqui (Biobío Region) $\left(\mathrm{CV}_{\mathrm{CL}}=31.25\right)$, a unique secondary constriction from Yumbel (Ñuble Region), and a higher TLC in Collanco (Biobío Region). Even though there was no evident karyotypic separation between Chilean and Canadian lentils, there was greater heterogeneity in TLC among cultivars in Chile than among those from Canada. It is unknown what physiological differences these cytological variants might possess. Because L. culinaris in Chile is of agronomic importance, studies of conservation are recommended to safeguard cytotaxonomic races as a national genetic resource.
\end{abstract}

Keywords: cytotaxonomy, karyotypic asymmetry, lentils, secondary constrictions.

\section{RESUMEN}

La lenteja (Lens culinaris Medik.) pertenece a la familia de las leguminosas (Fabaceae), y posee beneficios a nivel nutricional, sustentable y de sistema de cultivos de rotación. Su ocurrencia y consumo en Chile se origina de las importaciones desde Canadá, pero las herramientas moleculares agrupan a las lentejas canadienses aparte de aquellas que se cultivan en zonas agroclimáticas de tipo mediterráneas como las de Chile. Estudios isoenzimáticos han demostrado una reducida distancia genética entre diferente material de germoplasma de la lenteja chilena. El presente trabajo caracteriza cultivares chilenos y procedencias regionales y los compara con aquellos de Canadá usando herramientas citotaxonómicas como fórmula cromosómica, índice de asimetría intercromosomal, longitud total de los cromosomas (TLC), y un detallado examen de la arquitectura de cada cromosoma. Encontramos estabilidad cromosómica entre todas las lentejas como $4 \mathrm{~m}+3 \mathrm{sm}$. Los resultados mostraron un bajo TLC, pero una mayor asimetría intercromosomal 
en las procedencias de Hualqui (Región del Biobío) $\left(\mathrm{CV}_{\mathrm{CL}}=31,25\right)$, una única constricción secundaria de Yumbel (Región de Ñuble), y un mayor TLC en Collanco (Región del Biobío). Aún cuando no hubo evidente separación cariotípica entre las lentejas Chilenas y Canadieses, hubo mayor variación en el TLC de los cultivares de Chile que de los de Canadá. Se desconoce qué diferencias fisiológicas podrian poseer estas variantes citológicas. Debido a que L. culinaris es de importancia agronómica en Chile, se recomiendan estudios de conservación para resguardar las razas citotaxonómicas como un recurso genético nacional.

Palabras clave: asimetría cariotípica, citotaxonomía, constricciones secundarias, lentejas.

\section{INTRODUCTION}

The understanding and conservation of plant diversity provides benefits for humans, such as in prospecting for natural chemical compounds helpful in medicine (Tharanathan \& Mahadevamma 2003; Al-Islam et al. 2012) or in use of phytodiversity for improvement of cultivated plants to meet challenges of future nutritional demands (Govindaraj et al. 2015). In this context it is especially important to evaluate genetic diversity in crops of agronomic importance.

Many cultivated crops belong to the legume family (Fabaceae), which consists of about 800 genera and 20000 species (Lewis et al. 2005). According to Stagnari et al. (2017), the benefits offered by legumes can be classified at three levels: good nutrition (Tharanathan \& Mahadevamma 2003; Al-Islam et al. 2012), high productivity (Liting et al. 2019), and a stable system of cultivation (Pacajes et al. 2002; Zander et al. 2016), all of which provide high significance for many zones of the world. Among the legumes, there exists a subgroup called the dry legumes (pulses), which are harvested for their dry seeds.

An important dry leguminous crop world-wide is the lentil (Lens culinaris Medik.). This annual, herbaceous, and autogamous species originated in the near East, and it was one of the crops from which agriculture developed in the Old World (Zohary 1999). In 2018, the lentil was the fifth most productive dry leguminous crop in the world with six million tons harvested (FAOSTAT 2020). In this same year, the largest producers were Canada, India, USA and Turkey, in that order, with Canada producing two million tons and $13953 \mathrm{hg} \mathrm{ha}^{-1}$ (FAOSTAT 2020).

The lentil was introduced to Chile in the 17th century with the arrival of the Spanish, and it became an important domesticated crop within the country. In 1979 Chile produced up to 31690 tons, but 2018/2019 production dropped significantly to only 1400 tons and $7642 \mathrm{hg} \mathrm{ha}^{-1}$ (FAOSTAT 2020). Lentils are now being grown by small farmers only in Maule, Ñuble, La Araucanía, and Biobío regions, the latter region showing the highest yields (ODEPA 2019). Due to low domestic production, Chile now imports a large portion (97\%; $14726 \mathrm{t}$ ) of its crop from Canada (ODEPA 2019).

Diversity within cultivated L. culinaris is classified principally on the basis of the diameter of its seeds, these being the microspermas $(2-6 \mathrm{~mm})$ and macrospermas (6-9 $\mathrm{mm}$ ) (Barulina 1930), with the latter plants also being taller and having heavier seeds (Sharma et al. 1995). The macrospermas also flower and fruit over a longer period of days.

Recent studies with molecular markers on germplasm of $L$. culinaris throughout the world have revealed three agro-ecological zones, the northern temperate region, the Mediterranean, and southern Asia (Khazaei et al. 2016). Studies on genetic diversity of $L$. culinaris in Chile are few, and hence there is no clear picture of the status of this crop within the country. The Instituto de Investigaciones Agropecuarias (INIA) has made an effort to generate cultivars that possess seeds of high caliber, e.g., Calpun-INIA and Super AraucanaINIA (Tay et al. 2001; Peñaloza et al. 2007) and resistant to "la roya" (a devastating leaf rust, Uromyces fabae (Pers.) de Bary). Rodríguez et al. (1999) completed an isozyme study that revealed low genetic distance among samples of Chilean germplasm, with $87.2 \%$ of Chilean lentils being incorporated in the same phenetic grouping. These results suggest that low genetic diversity exists within the naturalized Chilean lentils.

Another approach to recognize patterns of genetic variation within diverse crop plants is use of karyological data. These methods permit evaluation of differences in the number, form, and size of chromosomes, band polymorphisms, and architectural alterations in the presence of secondary restrictions or nuclear organizing regions (NORs; Guerra 2008). General cytotaxonomic studies on $L$. culinaris have revealed a chromosome number of $2 n=14$ (Bhattacharjee 1953; Sinha \& Acharia 1972; Balyan et al. 2002; Jha et al. 2015). The morphology of the chromosomes varies from metacentric, submetacentric, to subtelocentric or acrocentric (Sinha \& Acharia 1972; Manara \& Manara 1979; Ladizinsky \& Muehlbauer 1993; Rehman \& Altaf 1994; Balyan et al. 2002; Gaffarzadeh-Namazi et al. 2007; Jha et al. 2015). Size of the individual chromosomes varies from 3.0 to $12.5 \mu \mathrm{m}$, 
depending upon which cultivar is examined, whereas the total length of the chromosomes (TLC) ranges from 28 to $121 \mu \mathrm{m}$ (Sinha \& Acharia 1972; Naithani \& Sarbhoy 1973; Manara \& Manara 1979; Rehman \& Altaf 1994; Gaffardazeh-Namazi et al. 2007; Jha et al. 2015). Secondary constrictions range from 0 to 3 (Battacharjee 1953; Sinha \& Acharia 1972; Naithani \& Sarbhoy 1973; Kumar et al. 2001; Galasso et al. 2001; Balyan et al. 2002; Gaffarzadeh-Namazi et al. 2007; Jha et al. 2015).

In the present study, we contribute to a better understanding of Chilean lentils by characterizing cytotaxonomically selected Chilean cultivars and accessions and comparing these with accessions from Canada. Specific data involve chromosome formula, indexes of chromosomal asymmetry, total length of chromosomes, and a detailed examination of the architecture of each of the chromosomes.

\section{MATERIALS AND METHODS}

\section{Plant Material}

Five accessions and two cultivars of Lens culinaris Medik. were utilized from Chile, plus three cultivars from Canada (Líder, Martini, Campo Lindo) obtained from Chilean supermarkets. For the Chilean accessions, these were obtained from small farmers in distinct localities of the Nuble (Yumbel, Ninhue) and Biobío (Collanco, Hualqui, Los Ángeles) Regions. Finally, the Chilean cultivars, Calpun-INIA and Super AraucanaINIA, were obtained from the Instituto de Investigaciones Agropecuarias (INIA).

\section{Preparation of plant material}

Seeds of $L$. culinaris were thoroughly hydrated in Petri dishes at room temperature $\left(18-22^{\circ} \mathrm{C}\right)$, germinating after $4 \mathrm{~d}$. This was followed by an antimitotic treatment of 8-hydroxyquinoline in the darkness at $4{ }^{\circ} \mathrm{C}$ for $24 \mathrm{~h}$. Later, the germinated seeds were fixed in ethanol/acetic acid (ratio 3:1) and kept in the darkness at $4{ }^{\circ} \mathrm{C}$. The root tips were subsequently excised from the seeds and washed with distilled water, followed by maceration with $\mathrm{HCl} 0.5 \mathrm{~N}$ at $45^{\circ} \mathrm{C}$ for 17 min. Immediately the root tips were washed in distilled water and placed on a microscope slide to which was added a drop of distilled water to titrate the tissue. The root tips were then squashed in a drop of $1 \%$ aceto-orcein for observation under the microscope.

Seven metaphase plates were observed for each cultivar and accession. Data obtained were: long arm/short arm ratio of the chromosomes following the modified method of Levan et al. (1964); and indices of the interchromosomal (coefficient of variation of chromosome length; $\mathrm{CV}_{\mathrm{CL}}$ ) and intrachromosomal asymmetry (mean centromeric asymmetry; $M_{C A}$ ) of the karyotypes (Peruzzi \& Eroglu 2013). For measuring dimensions of the chromosomes, the software Micromeasure (Reeves 2001) was used. Statistical analyses were done with the software Past 3.26b (Hammer et al. 2001).

\section{RESULTS AND DISCUSSION}

\section{UNIFORMITY OF CHROMOSOMAL FORMULA}

As can be observed in the metaphase plates (Fig. 1), all samples of $L$. culinaris analyzed in this study showed $2 n=14$ chromosomes, as has been reported previously (Bhattacharjee 1953; Sinha \& Acharia 1972; Balyan et al. 2002; Jha et al. 2015). The chromosomal formula was mostly $4 m+3 s m$ (Fig. 2) with no differences being detected between Chilean and Canadian cultivars and accessions, probably due to the frequent introduction of Canadian lentils to Chile. There were two exceptions: Collanco and Campo Lindo, which had $3 \mathrm{~m}+4 \mathrm{sm}$. Chromosome 1 in these two samples can be defined as submetacentric (following Levan et al. 1964), although the standard deviation might permit one alternatively to consider it as metacentric. The important point is that these samples were effectively distinct from the others.

In studies in other regions of the world, uniformity of the chromosome formula of $4 \mathrm{~m}+3 \mathrm{sm}$ has also been documented, e.g., in cultivars from Iran (Gaffarzadeh-Namazi et al. 2007) and also from India, but here with a slight difference of $4 m+2 s m+1 s t$ (Jha et al. 2015).

\section{VARIATION IN NUMBER OF SECONDARY CONSTRICTIONS}

Among the cultivars and accessions from Canada and Chile, there is variation in number of secondary constrictions, 4 to 5 from those in Canada and 4 to 6 from those in Chile (Fig. 3). In Chile this variation is due principally to the six secondary constrictions from Yumbel, which has a distinctive secondary subtelomeric constriction on chromosome 2 (Fig. 3). This constriction is related to the ribosomal gene $5 \mathrm{~S}$, which is positioned in a subtelomeric zone of chromosome 2 (Balyan et al. 2002) or 1 (Galasso et al. 2001). Three nuclear organizing regions (NORs) have been reported previously (Galasso et al. 2001; Balyan et al. 2002), one of 5S rDNA in a subtelomeric zone on chromosome 1 or 2 , which correlates with the secondary subtelomeric constriction observed in Yumbel, and another for the 18S-5.8S-25S rDNA in an easily observable centromeric zone on chromosome 3 or 4 (Fig. 2). In addition, we also observed a secondary subcentromeric constriction on chromosome 6 that is related to the position of $5 \mathrm{~S}$ rDNA on the same chromosome (also reported by Balyan et al. 2002 and Galasso et al. 2001). Another secondary constriction that has not been reported previously is a centromeric type found on chromosome 1 (Fig. 1). Given these variations in the 
presence of secondary constrictions, it would be important in the future to obtain more information, especially from fluorescence in situ hybridization (FISH).

\section{TOTAL LENGTH OF CHROMOSOMES (TLC)}

A broader variation in total length of chromosomes (TLC) exists among Chilean cultivars and accessions than among those from Canada, with 150.86-234.28 $\mu \mathrm{m}$ in the former, and 176.11-190.92 $\mu \mathrm{m}$ in the latter (Fig. 4). Hualqui possesses TLC of $150.86 \mu \mathrm{m}$, the lowest among samples examined, and significantly differentiated from the highest TLCs in Yumbel and Collanco ( $p=0.04$ and $p=5.5 \times 10^{-5}$, respectively) (Table 2 ). Collanco, with the largest TLC of $234.28 \mu \mathrm{m}$, is differentiated significantly from Ninhue, Los Ángeles, and Hualqui $(p=3.1$ $\times 10^{-4}, p=6.0 \times 10^{-3}$ and $p=5.5 \times 10^{-5}$, respectively) (Table 2). Other studies have reported TLC for cultivars of $L$. culinaris in different countries that range from 28 to $121 \mu \mathrm{m}$ (Sinha \&
Acharia 1972; Naithani \& Sarbhoy 1973; Manara \& Manara 1979; Rehman \& Altaf 1994; Gaffarzadeh-Namazi et al. 2007; Jha et al. 2015), revealing that this character is quite variable. The results obtained in the present study indicate TLC even higher than those reported previously.

\section{INTERCHROMOSOMAL ASYMMETRY}

Differences in the asymmetric karyotypes among Canadian and Chilean cultivars and accessions reveal clusters that are somewhat distinct from each other between the two regions (Fig. 5). Separating these data into cultivars and accessions, however, shows that only Hualqui (Fig. 6) is separated from all other samples. With exclusion of these data, the cultivars and accessions from Chile and Canada are completely overlapping. The interchromosomal asymmetry $\left(\mathrm{CV}_{\mathrm{CL}}\right)$ of the Hualqui accession was an average 31.25 , significantly differentiated from all the rest of the cultivars or accessions (Table 1).

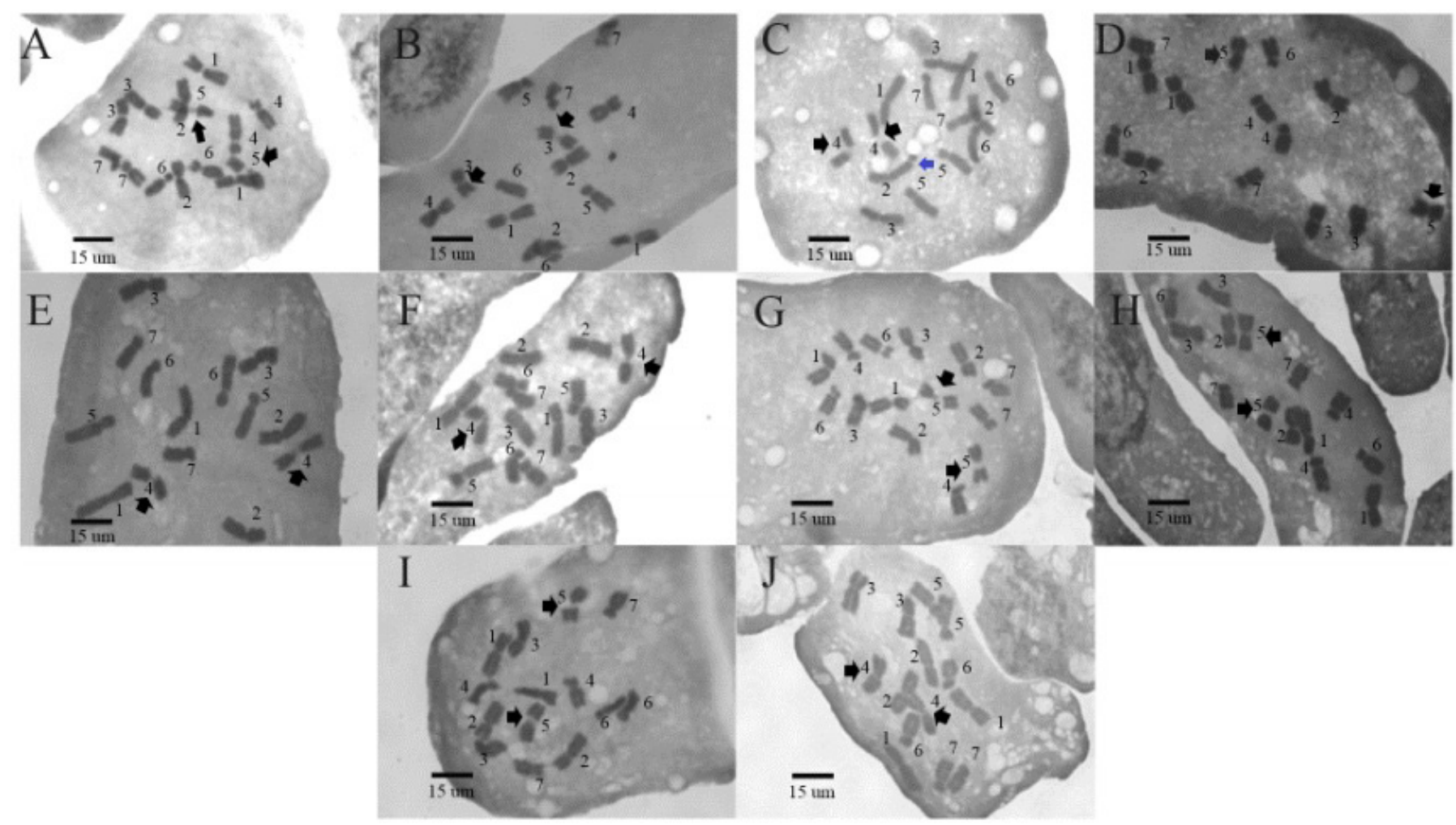

FIGURE 1. Metaphase plates from each cultivar and accession of Lens culinaris, with chromosomes numbered: Calpún-INIA (A), Super Araucana-INIA (B), Yumbel (C), Ninhue (D), Collanco (E), Hualqui (F), Los Ángeles (G), Campo Lindo (H), Líder (I), Martini (J). Black arrows indicate the most representative secondary constrictions. The blue arrow indicates the single subtelomeric secondary constriction. / Placas metafásicas de cada cultivar y procedencia de Lens culinaris, con cromosomas numerados: Calpún-INIA (A), Super Araucana-INIA (B), Yumbel (C), Ninhue (D), Collanco (E), Hualqui (F), Los Ángeles (G), Campo Lindo (H), Líder (I), Martini (J). Las flechas negras indican las constricciones secundarias más significativas. La flecha azul indica la única constricción secundaria subtelomérica. 
Galpún-INIA

Super Araucana-INIA

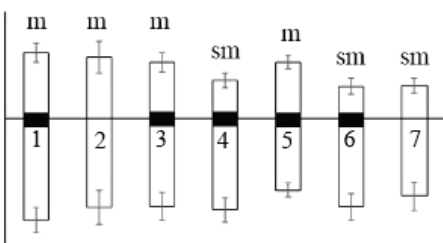

Gollanco
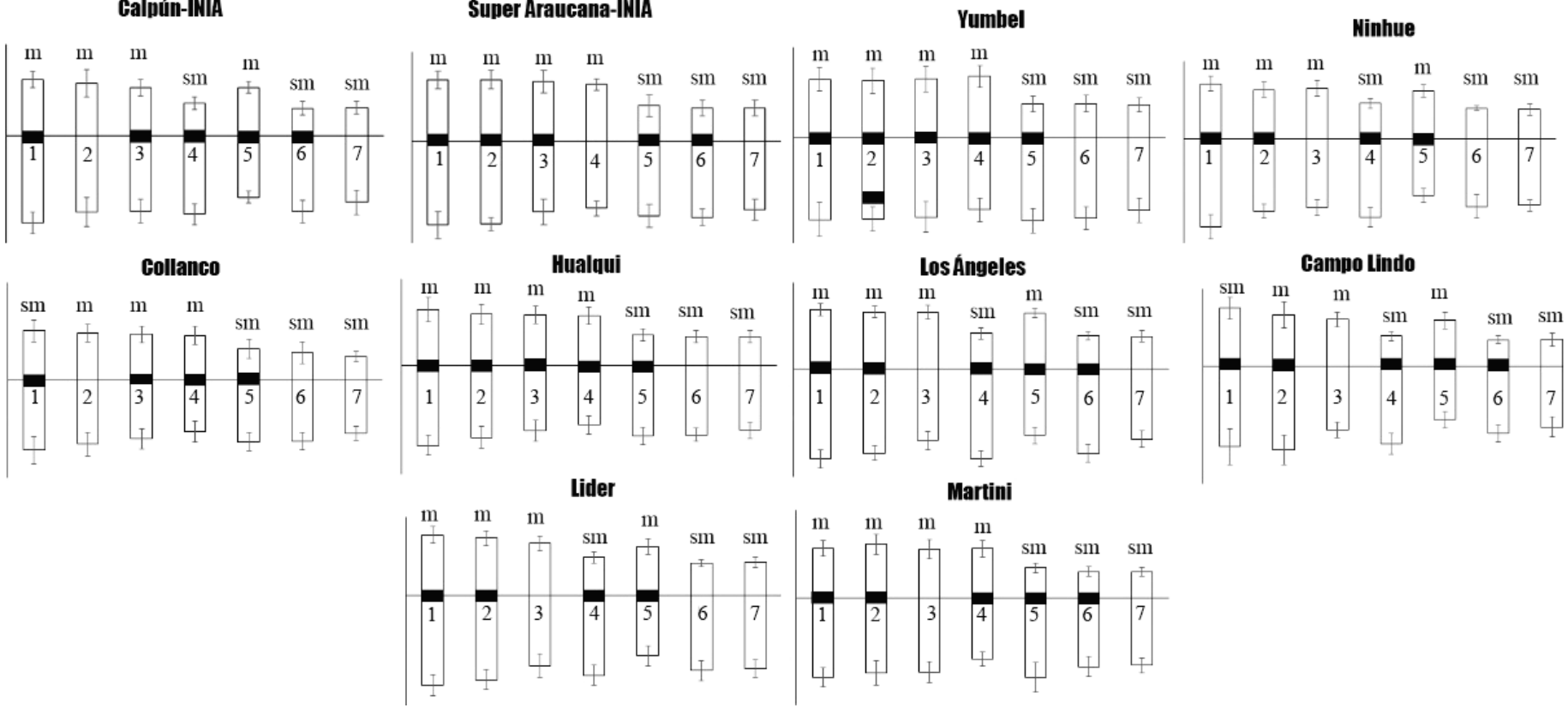

Martini

iner

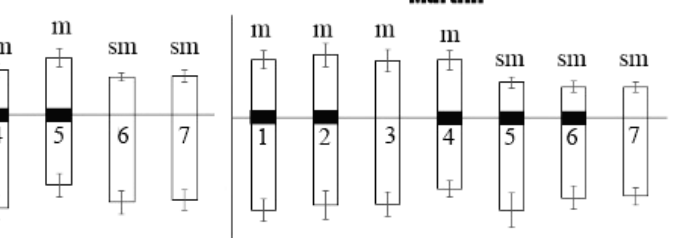

Figure 2. Idiograms of the cultivars and accessions of Lens culinaris evaluated in this study. The chromosomes are ordered according to their length; whiskers indicate standard deviations. The black areas represent secondary constrictions observed in metaphase plates. / Ideogramas de los cultivares y procedencias de Lens culinaris evaluados en este estudio. Los cromosomas están ordenados de acuerdo a su longitud, cada uno lleva su desviación estándar. Las áreas negras representan las constricciones secundarias observadas en las placas metafásicas.

TABLE 1. Tukey test for comparisons of the coefficient of variation of chromosome length $\left(\mathrm{CV}_{\mathrm{CL}}\right)$ index of the Hualqui accession with all other cultivars and accessions. / Test de Tukey para la comparación del índice de coeficiente de variación de la longitud del cromosoma $\left(\mathrm{CV}_{\mathrm{CL}}\right)$ de la procedencia de Hualqui con respecto a los demás cultivares y procedencias.

\begin{tabular}{ll}
\hline Comparisons with Hualqui & $\mathrm{CV}_{\mathrm{cl}}-\mathrm{p}$ value \\
\hline Calpún-INIA & $1.80 \times 10^{-11}$ \\
Super Araucana-INIA & $1.81 \times 10^{-11}$ \\
Ninhue & $1.80 \times 10^{-11}$ \\
Collanco & $1.81 \times 10^{-11}$ \\
Yumbel & $1.79 \times 10^{-11}$ \\
Los Ángeles & $1.79 \times 10^{-11}$ \\
Campo Lindo & $1.79 \times 10^{-11}$ \\
Líder & $1.80 \times 10^{-11}$ \\
Martini & $1.79 \times 10^{-11}$ \\
\hline
\end{tabular}

TABLE 2. Significant differences in Dunn test comparisons for total chromosome length (TLC). All p-values are adjusted by Bonferroni correction. / Diferencias significativas en comparaciones del test de Dunn para la longitud total del cromosoma (TLC). Todos los valores p están ajustados a la corrección de Bonferroni.

\begin{tabular}{lc}
\hline Comparisons & TLC -p value \\
\hline Hualqui - Yumbel & 0.04307 \\
Hualqui - Collanco & 0.00006 \\
Collanco - Los Ángeles & 0.00602 \\
Collanco - Ninhue & 0.00031 \\
\hline
\end{tabular}




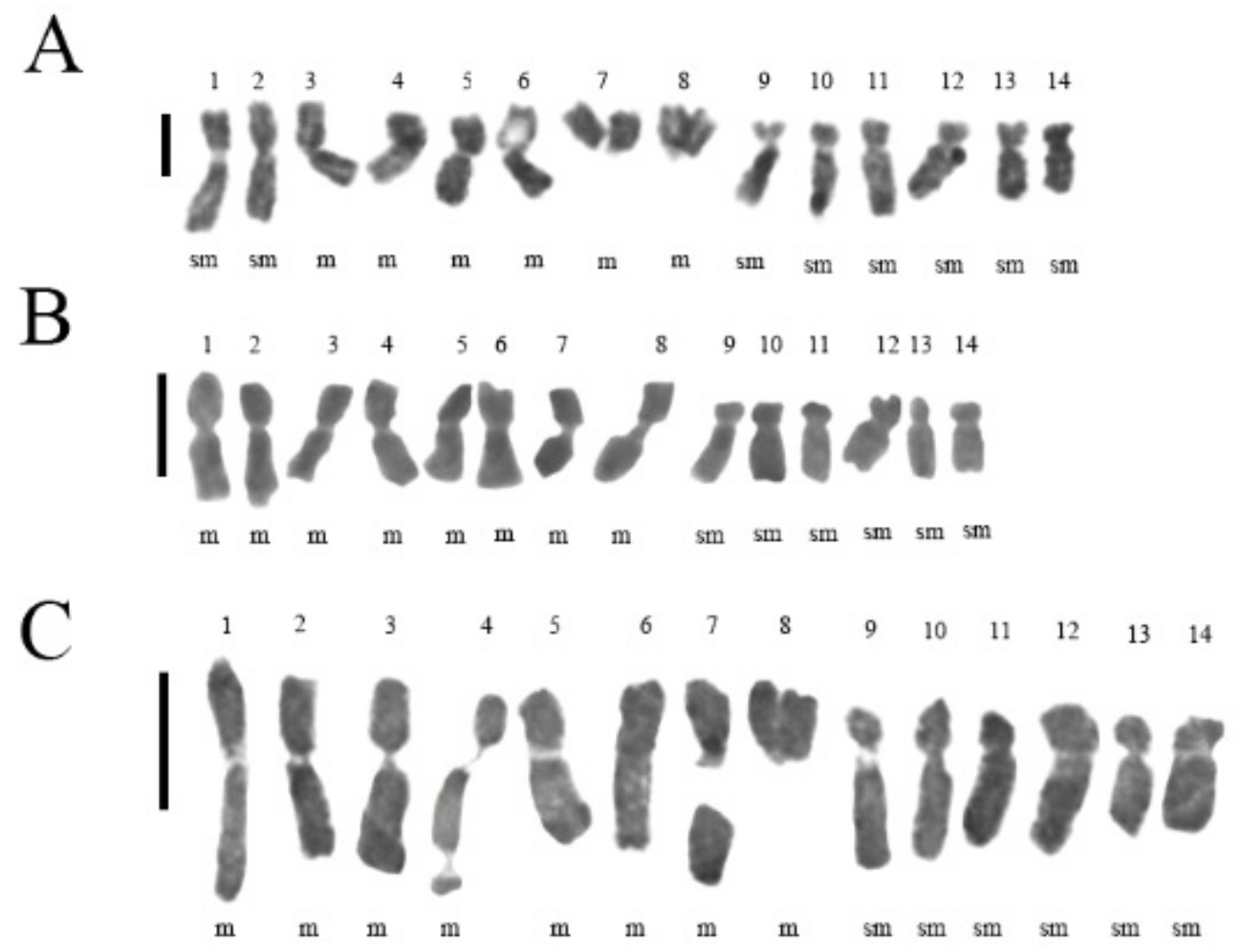

Figure 3. Karyotypes from the accessions of Collanco (A), Hualqui (B), and Yumbel (C). Scales $=10 \mu \mathrm{m}$. / Cariotipos de las procedencias de Collanco (A), Hualqui (B), y Yumbel (C). Escala $=10 \mu \mathrm{m}$.

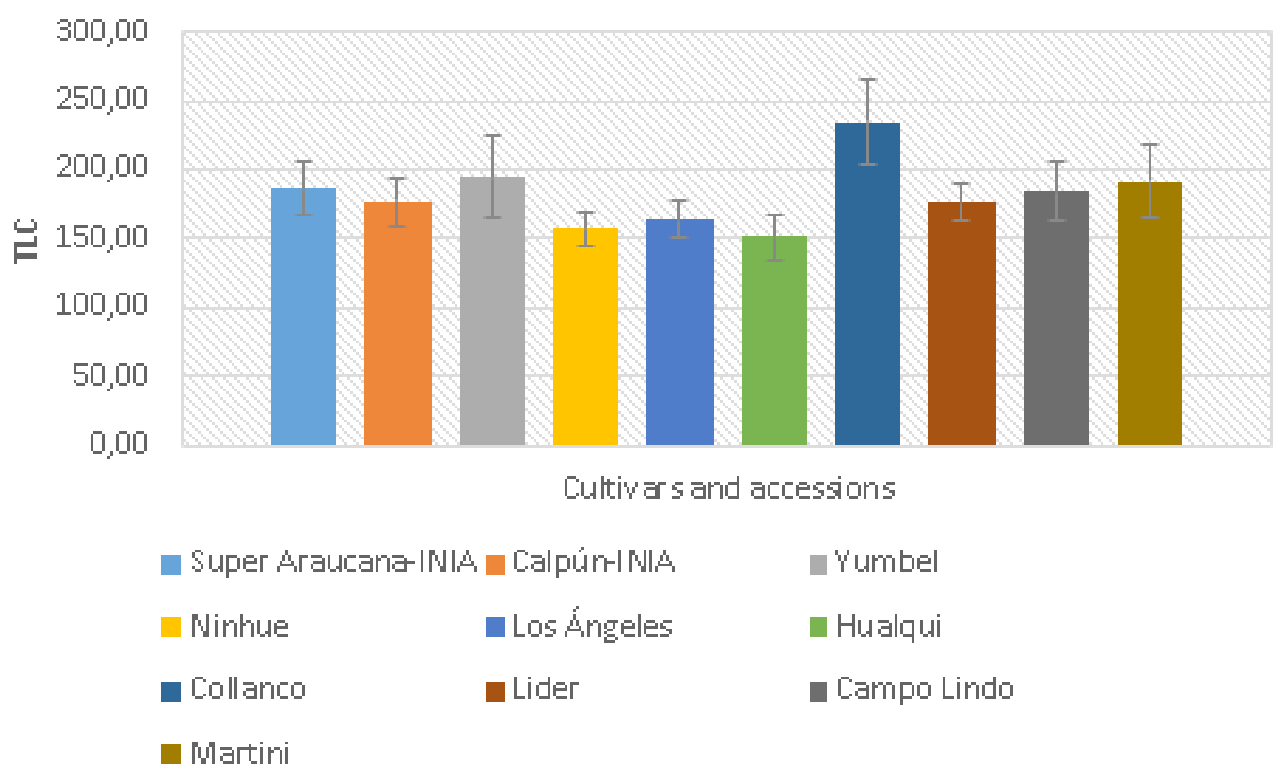

FIGURE 4. Total chromosome length (TLC) for each cultivar and accession evaluated in this study. / Longitud total del cromosoma (TLC) para cada cultivar y procedencia evaluada en este estudio. 


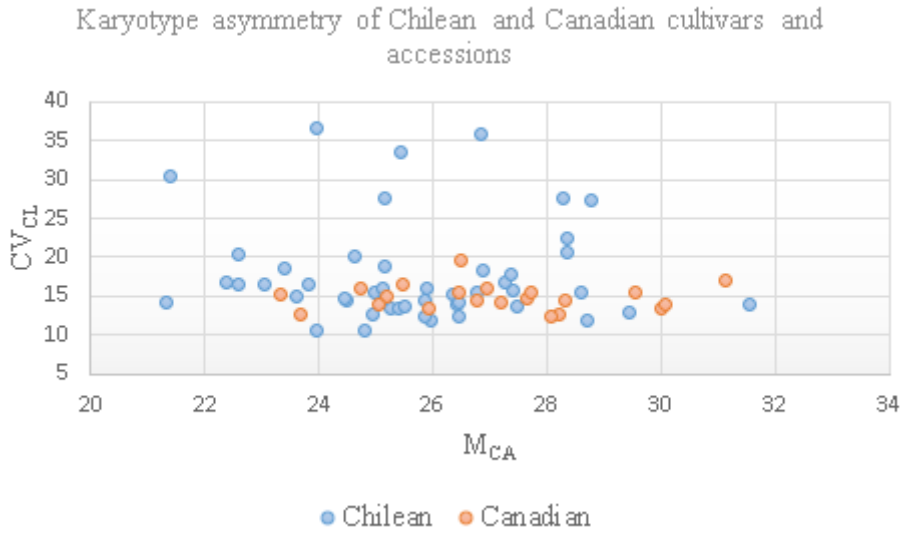

FigURE 5. Karyotypic asymmetry of the coefficient of variation of chromosome length $\left(\mathrm{CV}_{\mathrm{CL}}\right)$ and mean centromeric asymmetry $\left(\mathrm{M}_{\mathrm{CA}}\right)$ for the Chilean and Canadian cultivars and accessions of Lens culinaris. / Asimetría cariotípica del coeficiente de variación de la longitud del cromosoma $\left(\mathrm{CV}_{\mathrm{CL}}\right)$ y asimetría centromérica media $\left(\mathrm{M}_{\mathrm{CA}}\right)$ para los cultivares y procedencias de Lens culinaris chilenos y canadienses.

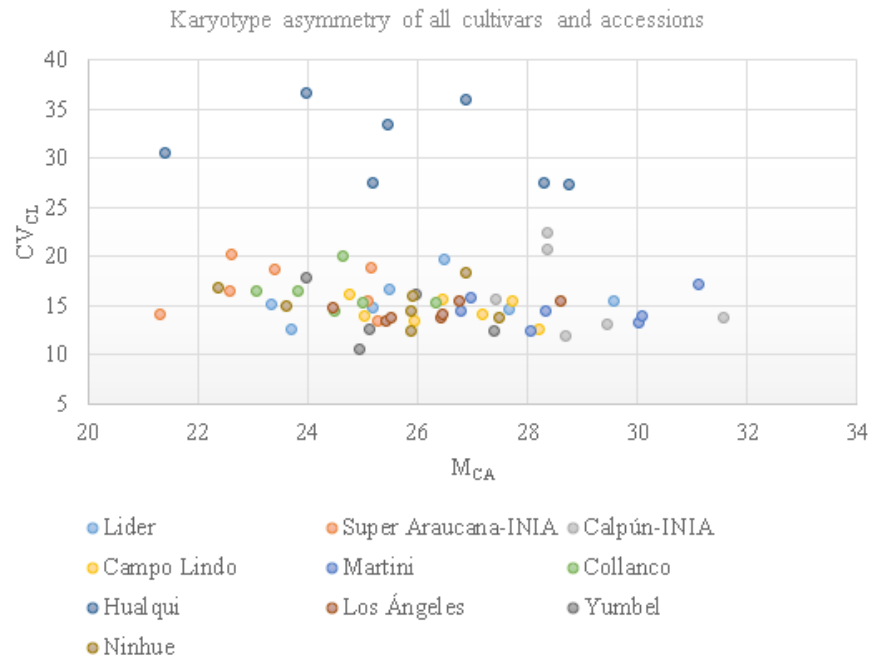

FIGURE 6. Asymmetric karyotype of the indices coefficient of variation of chromosome length $\left(\mathrm{CV}_{\mathrm{CL}}\right)$ and mean centromeric asymmetry $\left(M_{C A}\right)$ for each cultivar and accession of Lens culinaris evaluated in this study. The blue ellipse includes values from plants of Hualqui. / Asimetría cariotípica de los índices coeficiente de variación de la longitud del cromosoma $\left(\mathrm{CV}_{\mathrm{CL}}\right)$ y asimetría centromérica media ( $\mathrm{M}_{\mathrm{CA}}$ ) para cada procedencia y cultivar de Lens culinaris evaluado en este estudio. La elipse azul incluye valores de Hualqui.

Differences in intrachromosomal asymmetry $\left(\mathrm{M}_{\mathrm{CA}}\right)$ also exist between the Chilean 'Calpún-INIA' and 'Super Araucana-INIA' (Fig. 6; Pino-Palma \& Baeza-Perry 2019). One possible explanation for the interchromosomal asymmetric karyotype in Hualqui might be chromosomal rearrangements, possibly deletions, given that the lowest TLC occurs in this accession (Fig. 4). Vu et al. (2015) indicated that repair of a rupture of the DNA double helix can generate insertions or deletions, which can determine the size of the genome as consequence of the net value between insertions and deletions. Polymorphisms in some chromosomal bands have been found in cultivars of L. culinaris from Iran (GaffarzadehNamazi et al. 2007), which also might reflect processes such as chromosomal rearrangements, such as have been documented in cultivars of wheat (Schneider et al. 2003). In studies of other Chilean species, such as Alstroemeria ligtu L., differences in asymmetrical karyotypes have been suggested to correlate with environmental factors, such as type of soil, habitat, and distribution (Baeza et al. 2016). In addition, in two subspecies of Alstroemeria presliana Herb., karyotypic asymmetry appears to correlate with phenotypic variations in intensity of color of tepals and anthers (Baeza et al. 2015). 


\section{CONCLUSIONS}

In this karyological study of Lens culinaris, we have shown the broadest variation of total length of chromosomes (TLC) to occur within Chile. We found some Chilean accessions with distinct cytotaxonomic characteristics, such as Hualqui with marked interchromosomal asymmetry. Yumbel possesses a secondary subtelomeric constriction on chromosome 2, and Collanco has the highest TLC. It is not known that the physiological implications might be from these variations, but further study and understanding of $L$. culinaris in Chile is certainly warranted. With further sampling, it might be possible to detect consistent cytotaxonomic signatures for each of these regions, distinct from those in Canada, which would permit identification of origin for any marketable product. The agronomic importance of this species in Chile recommends protection of these cytotaxonomic variants as a national genetic resource.

\section{ACKNOWLEDGEMENTS}

Departamento de Botánica, Facultad de Ciencias Naturales y Oceanográficas, Universidad de Concepción. Instituto de Investigaciones Agropecuarias (INIA), Chile, for contribuite with samples of Calpún-INIA and Super Araucana-INIA cultivars.

\section{REFERENCES}

Al-Islam, M., Rabah, H., Yousef, A. 2012. Role of lentils (Lens culinaris L.) in human health and nutrition: a review. Mediterranean Journal of Nutrition and Metabolism 6 : 3-16.

Baeza, C., Finot, V.L., Ruiz, E. 2015. Comparative karyotype analysis of populations in the Alstroemeria presliana Herbert (Alstroemeriaceae) complex in Chile. Genetics and Molecular Biology 38: 199-204.

Baeza, C., Finot, V., Ruiz, E., Carrasco, P., Novoa, P., Stuessy, T. 2016. Comparative karyotypic analysis and cytotaxonomy in the Alstroemeria ligtu L. (Alstroemeriaceae) complex of Chile. Brazilian Journal of Botany 39: 305-313.

Balyan, H.S., Houben, A., Ahne, R. 2002. Karyotype analysis and physical mapping of $18 \mathrm{~S}-5.8 \mathrm{~S}-25 \mathrm{~S}$ and $5 \mathrm{~S}$ ribosomal RNA loci in species of genus Lens Miller (Fabaceae). Caryologia 55: 121-128.

Barulina, H. 1930. Lentils of the USSR and of other countries. Bulletin of Applied Botany, Genetics, and Plant Breeding 40 (supplement): 1-309.
Bhattacharjee, S.K. 1953. Cytogenetics of Lens esculenta Moench. Caryologia 5: 159-166.

FAOSTAT. 2020. Datos sobre alimentación y agricultura. FAO, Italia, Roma. Available at http://www.fao.org/faostat/ es/\#home (Accessed: 2020).

Gaffarzadeh-Namazi, L., Asghari-Zakaria, R., Babaeian, N., Kazemi-Tabar, K. 2007. Comparative study of chromosome morphology and C-banding patterns in 31 several genotypes of Lens culinaris. Pakistan Journal of Biological Sciences 10: 1811-1816.

Galasso, I., Schmidt, T., Pignone, D. 2001. Identification of Lens culinaris ssp. culinaris chromosomes by physical mapping of repetitive DNA sequences. Chromosome Research 9: 199-209

Govindaraj, M., Vetriventhan, M., Srinivasan, M. 2015. Importance of genetic diversity assessment in crop plants and its recent advances: An overview of its analytical perspectives. Genetics Research International 2015: 431487.

Guerra, M. 2008. Chromosome numbers in plant cytotaxonomy: Concepts and implications. Cytogenetics and Genome Research 120: 339-350.

Hammer, O., Harper, D.A.T., Ryan, P.D. 2001. PAST: Paleontological statistics software package for education and data analysis. Palaeontologia Electronica 4(1): 4.

Jha, T.B, Mahanti, A., Ghorai, A. 2015. Karyotype analysis of Indian lentils through EMA based Giemsa staining. Caryologia 68: 280-288.

Khazaei, H., Caro, C.T., Fedoruk, M., Diapari, M., Vandenberg, A., Coyne, C.J. 2016. Genetic diversity of cultivated lentil (Lens culinaris Medik.) and its relation to the world's agroecological zones. Frontiers in Plant Science 7: 1093.

Kumar, S., Balyan, H.S., Ramesh, B., Singh, S.P., Gupta, P.K. 2001. A study of nucleolar organizers in lentil using FISH and spore quartet analysis. Cytologia 66: 247-252.

Ladizinsky, G., Muehlbauer, F.J. 1993. Wild lentils. Critical Reviews in Plant Sciences 12: 169-184.

Levan, A., Fredga, K., Sandberg, A. 1964. Nomenclature for centromeric position on chromosomes. Hereditas 52: 201-220.

Lewis, G., Schrire, B., Mackinder, B., Lock, M. 2005. Legumes of the world. Royal Botanic Gardens, Kew, Richmond. 592 pp.

Liting, L., Knight, J.D., Lemke, R.L., Farrel, R.E. 2019. A side-byside comparison of biological nitrogen fixation and yield of four legume crops. Plant and Soil 442: 169-182.

Manara, N.T.F., Manara, W. 1979. Cariotipo de quatro linhages de lentilha (Lens culinaris Medic.) Revista do Centro de Ciencias Rurais 9: 409-417.

Naithani, S.P., Sarbhoy, R.K. 1973. Cytological studies in Lens esculenta Moench. Cytologia 38: 195-203. 
ODEPA. 2019. Información regional de superficie sembrada, producción y rendimientos anuales. Oficina de Estudios y Políticas Agrarias. https://www.odepa.gob.cl/estadisticasdel-sector/estadisticasproductivas (Accessed: 2019).

Pacajes, G., Franco, J., Esprella, R., Main, G. 2002. Efecto de diferentes cultivos y prácticas culturales sobre la multiplicación del nemátodo quiste de la papa (Globodera spp.) en Bolivia. Revista Latinoamericana de la Papa 13: 52-65.

Peñaloza, E., Tay, J., France, A. 2007. Calpún-INIA, cultivar de lenteja (Lens culinaris Medik.) de grano grande y resistente a roya. Agricultura Técnica (Chile) 67: 68-71.

Peruzzi, L., Eroglu, H.E. 2013. Karyotype asymmetry: Again, how to measure and what to measure? Comparative Cytogenetics 7: 1-9.

Pino-Palma, R., Baeza-Perry, C. 2019. Citotaxonomía de los cultivares de Lens culinaris Medik. Calpún-INIA y Super Araucana-INIA. Chloris Chilensis. Año 22(2).

Reeves, A. 2001. MicroMeasure: A new computer program for the collection and analysis of cytogenetic data. Genome 44: 239-443.

Rehman, S.U., Altaf, C.M. 1994. Karyotypic studies in Lens culinaris Medik., ssp. macrosperma cv. Laird $\times$ Precoz. Pakistan Journal of Botany 26: 347-352.

Rodríguez, M., Paredes, M., Becerra, V. 1999. Diversidad isoenzimática del germoplasma de lentejas (Lens culinaris Medik) naturalizado en Chile. Agricultura Técnica (Chile) 59: 186-195.

Schneider, A., Linc, G., Molnár-Láng, M. 2003. Fluorescence in situ hybridization polymorphism using two repetitive
DNA clones in different cultivars of wheat. Plant Breeding 122: 396-400.

Sharma, S.K., Chahota, R.K., Chuni, L. 1995. Genetic diversity and agronomic evaluation of microsperma and macrosperma lentils. Genetic Resources and Crop Evolution 42: 217222.

Sinha, S.S.N., Acharia, S.S. 1972. Karyotype analysis in some varieties of Lens culinaris. Cytologia 37: 673-683.

Stagnari, F., Maggio, A., Galieni, A., Pisante, M. 2017. Multiple benefits of legumes for agriculture sustainability: An overview. Chemical and Biological Technologies in Agriculture 4: 2.

Tay, J.U., France, A., Paredes, M. 2001. Super Araucana-INIA: Una nueva variedad de lenteja (Lens culinaris Med.) chilena de grano grande. Agricultura Técnica (Chile) 61: 385-389.

Tharanathan, R.N., Mahadevamma, S. 2003. Grain legumes - a boon to human nutrition. Trends in Food Science and Technology 14: 507-518.

Vu, G.T.H., Schmutzer, T., Bull, F., Cao, H.X., Fuchs, J., Tran, T.D. 2015. Comparative genome analysis reveals divergent genome size evolution in a carnivorous plant genus. The Plant Genome 8: 1-14.

Zander, P., Amjath-Babu, T.S., Preissel, S., Reckling, M., Bues, A., Schläfke, N. 2016. Grain legume decline and potential recovery in European agriculture: A review. Agronomy for Sustainable Development 36: 26.

Zohary, D. 1999. Monophyletic vs. polyphyletic origin of the crops on which agriculture was founded in the Near East. Genetic Resources and Crop Evolution 46: 133-142.

Received: 06.11.2020

Accepted: 21.03.2021 